\title{
Micro-hydro Resources Development as Hybrid Renewable Energy System in the Ambapa Village
}

\author{
Muhammad Yusan Naim ${ }^{1}$, Henny Pramoedyo ${ }^{2}$, Nuddin Harahab ${ }^{3}$, Syarifuddin Nodjeng ${ }^{4}$ \\ \{yusannaim@yahoo.com.au ${ }^{1}$, syarifuddinnojeng@gmail.com ${ }^{4}$ \} \\ Universitas Muslim Indonesia, Indonesia ${ }^{1,4}$ \\ Universitas Brawijaya, Indonesia ${ }^{2,3}$
}

\begin{abstract}
This research presents the concept of developing Micro-hydro Resource with limited water discharge to become sustainable of Hybrid Renewable Energy System (HRES). Hybrid of Micro Hydro-Solar Photovoltaic (PV) energy sources and limiting the energy use of each household carried out simultaneously in both the rainy and dry seasons are the solutions so that not only electricity supply can be sustainable but also low cost. The operation of the Hybrid Renewable energy system is not as simple as using Micro-hydro resources so a Hybrid Optimization Model of Electric Renewable (HOMER) application program is needed. This application program is used to calculate the Total Initial Capital, Cost of Energy (COE) and Excess Energy from HRES. This simulation uses an application program that refers to the lowest Net Present Cost (NPC) value with a life time of 25 years. The simulation result shows that the lowest NPC value is Rp. 863,974,768, the Total Initial Capital needed to develop Micro-hydro Resources to become HRES in Ambapa village is Rp. 392,470,986, -. The contribution of energy produced from Micro-hydro energy sources is $103,780 \mathrm{kWh} / \mathrm{yr}(84.20 \%)$ and PV energy sources is $18,810 \mathrm{kWh} / \mathrm{yr}(15.8 \%)$. The $100 \%$ total contribution is $122,590 \mathrm{kWh} / \mathrm{yr}$ with COE of Rp1,107/kWh. The cost of electricity is Rp. 48,238/month with the energy consumption limits per household of $1,450 \mathrm{wh} /$ day.
\end{abstract}

Keywords: Energy Sources, Hybrid Renewable Energy System, Cost of Energy, Net Present Cost, Sustainable.

\section{Introduction}

The population in 2014 at Ambapa Village was 435 people with 115 households. Ambapa Village is one of the remote villages in Tinondo sub-district, East Kolaka Regency, Southeast Sulawesi Province, with an area of $15.38 \mathrm{~km} 2$, and surrounded by mountains and road conditions that are still lacking, so PLN electricity network has not yet entered into. The village area of Ambapa. Most of the people of Ambapa village are pepper farmer and patchouli, the rest are state and merchant officers [1]. Electricity energy needs in the village of Ambapa people use small generators, while the less capable people still use kerosene lamps. This condition is very concern and burden the community, because the price of gasoline and kerosene are very expensive and supplies are limited. Therefore, on the initiative of Village Unit Cooperatives and proposed village government Ambapa in 2014 was built Micro-hydro with nominal power $100 \mathrm{KW}$, in hopes that the generator can supply electrical energy according to the needs of the community every day so that the people of Ambapa village have been able to enjoy electrical energy at all times, both during the day 
and night.

But since the beginning of 2015, Micro-hydro only operates during the day and can no longer supply energy at night during the dry season. In the dry season, Micro-hydro is not operated again at night, even Micro-hydro is threatened to not operate. Therefore, the development of Micro-hydro is needed by conducting the blend of Micro-hydro and PV energy sources that have a variation of solar radiation of 4.8 to $5.4 \mathrm{kwh} / \mathrm{m}^{2}$ per day [2].

This research used programs of HOMER application, because the application program is widely used researchers and has been proven in calculating Hybrid Renewable Energy System [3], such as in calculating investments and energy prices, calculates the size of each energy source and calculates the contribution of the output power of each resource and the cost of investment.

\section{Basic Theory}

Micro-hydro is the most renewable energy source used in remote villages. The sustainability of Micro-hydro operations is highly dependent on the large flow of river water that continues to flow throughout the year [4]. Large water discharge continuously will certainly guarantee the continuity of Micro-hydro's operation. Even though the amount of power raised by Micro-hydro is also dependent on the height of the river waterfall, but the height of the plunge does not increase and decrease every year. So, Micro-hydro is very dependent on river water discharge throughout the year. Therefore, river water discharge needs to be maintained so that Micro-hydro operations can be sustained. However, water discharge will decrease during the long dry season in a particular month, so that Micro-hydro operations experience energy supply disruptions to the user community, even Micro-hydro operations sometimes stop for one month. Therefore, efforts must be made so that the supply of electrical energy continues to run despite natural conditions that are difficult to avoid. One of the solutions is to develop micro-hydro resources into Hybrid Energy System resources in the form of a hybrid of existing micro-hydro resources with Photovoltaic resources. The magnitude of photovoltaic power is highly dependent on solar radiation. The greater the solar radiation the greater the power generated. Likewise, the availability of abundant potential solar energy sources with an average solar radiation intensity of around $4.8 \mathrm{kWh} / \mathrm{m}^{2}$ per day in all regions of Indonesia including case regions, making the energy source as an alternative energy source to cover the technical short comings of micro-hydro in meeting the electricity needs of the community at any time.

Solar power in the form of solar radiation is converted through a Photovoltaic (PV) module into electricity called a solar power plant. This power plant is not necessarily cost from all technical deficiencies, because the power source of solar power plants can only operate during the day 7-8 hours/day in the dry season and 5-6 hours/day [2] in the rainy season and the efficiency value is very low $(14 \%-16 \%)$. Therefore, it is necessary to develop power plant micro-hydro existing resources by combining the two resources (Micro-hydro and Photovoltaic) to cover each technical deficiency. According to Kanata [5], combining two or more generators with different primary energy sources is called a Hybrid System, so the merging of Micro-hydro and Photovoltaic resources to supply community electricity needs called the Hybrid Renewable Energy System or Sustainable Hybrid Power Plant. 


\subsection{Micro-hydro Resources Development Method}

In this study, the development of Micro-hydro to RES is the change of Micro-hydro to Hybrid Renewable Energy System (HRES) by adding 1 piece or blending 2 or more energy sources. Such as PV/Micro-hydro, PV/Wind, and PV/Micro-hydro, Diesel/Wind, and other renewable energy [6]. Nevertheless, the selection of the implementation of HRES is adjusted to the utilization and potential of local areas. For example, Ambapa village only has 2 natural potential that is the potential of Micro-hydro and PV, so that the HRES chosen is PV/Microhydro. These energy sources are overall and certain conditions can operate more economically and efficiently. The optimization of stage HRES can be seen in Figure 1.

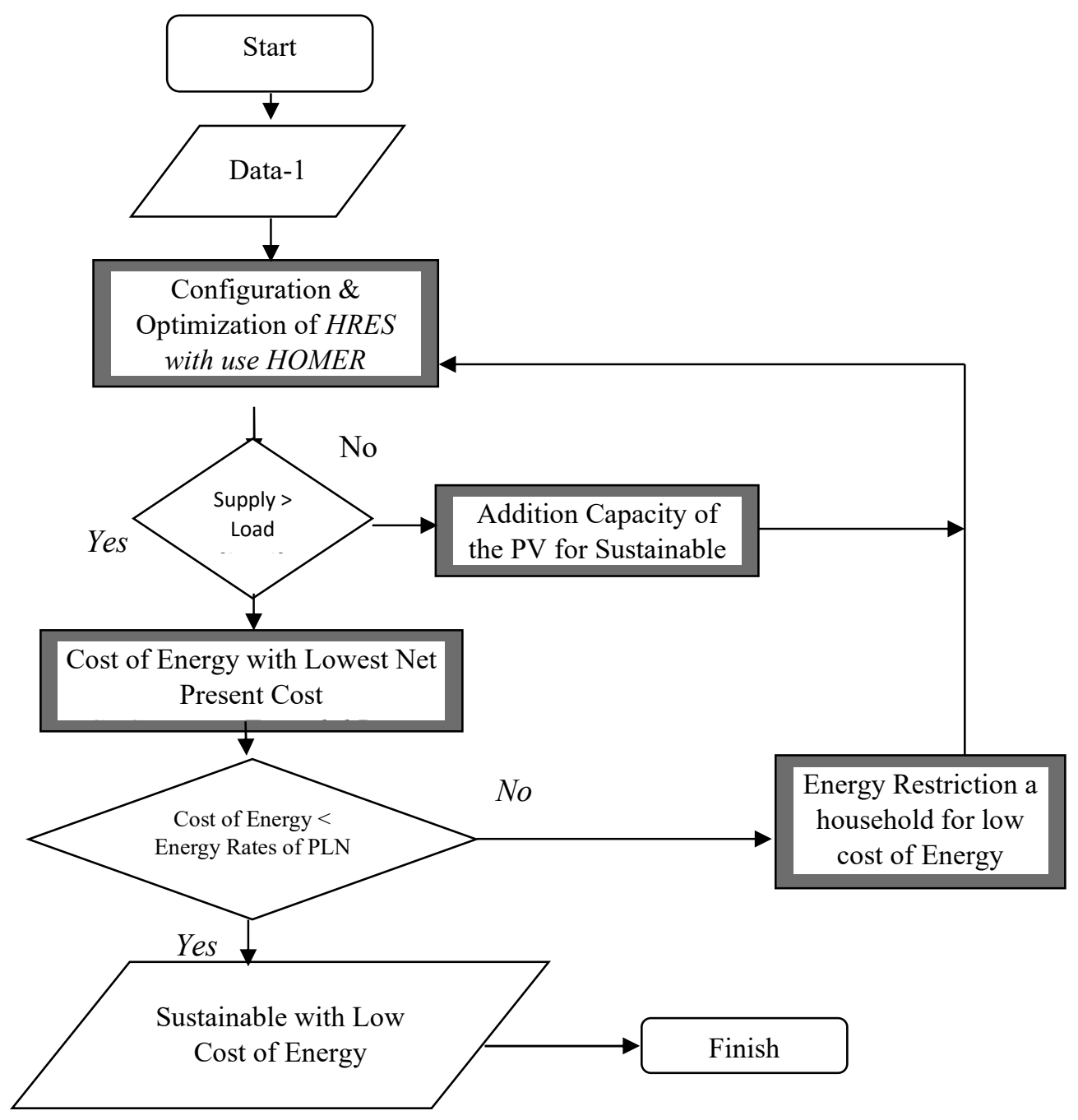

Fig. 1. Micro-hydro Resources Development Method 


\subsection{Hybrid Optimization Model of Energy Renewable}

Sources of Micro-hydro energy that have been/will experience the congestion changed by adding some key PV components, such as the HRES configuration display [3] in Figure 2.

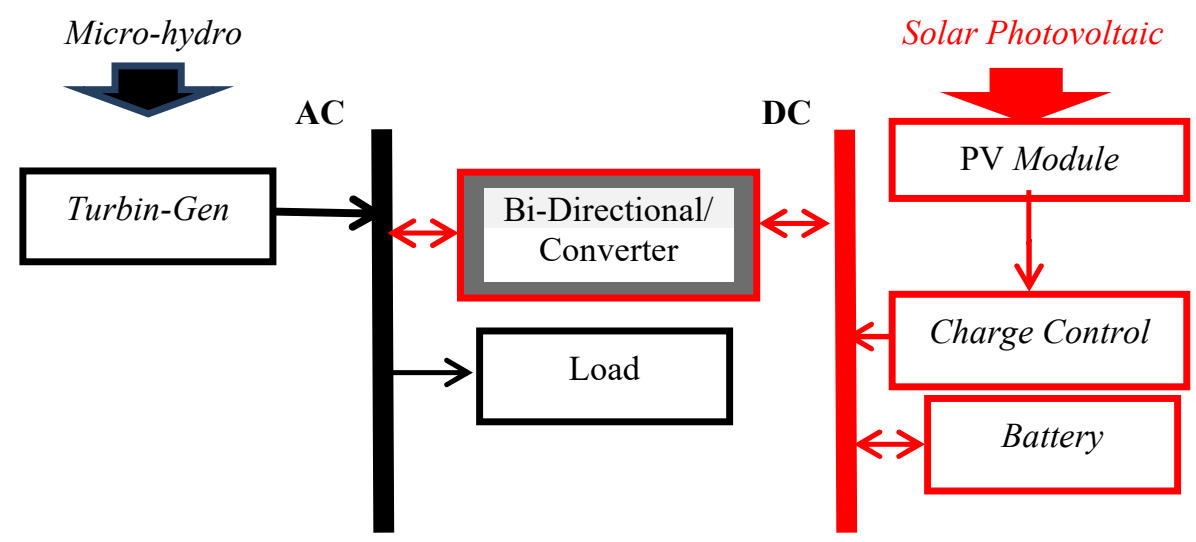

Fig. 2. Configuring of Micro-hydro Development into HRES.

Based on the change configuration in Figure 2, it can be created schematic HRES corresponding input model in HOMER application program [7]. The application Program is one of the popular tools for HRES design that uses renewable energy. HOMER simulates and optimizes both stand-alone and grid-connected power generation systems consisting of a combination of renewable energy in serving the base and peak loads. HOMER can also decide for every hour, whether the diesel/gasoline generators operate and whether the battery is charged or emptied. HOMER further determines the best combination of HRES and then sets the cost of components and system operations during the life time, such as initial costs, replacement cost of components, O \& M costs, fuel costs, etc. [8]. As for schematic HRES on the HOMER application program shown on Figure 3.

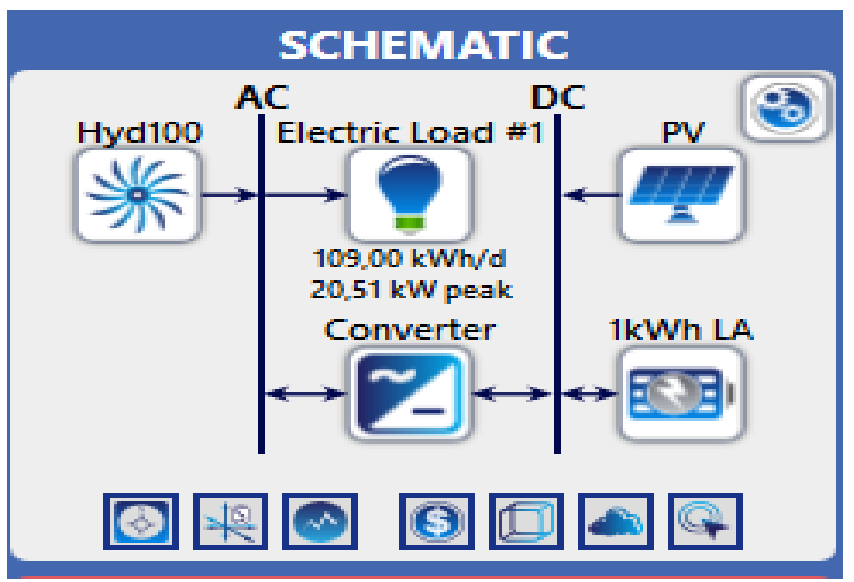

Fig. 3. Schematic of HRES 
In figure 3 is a picture that shows the schematic of HRES. HOMER application program consisting of several main components of the Micro-hydro hybrid with PV, consisting of 3 main components, namely:

a) The main components of Micro-hydro consist of technical and economic specifications of generators and turbine

b) Main components of PV consist of technical specifications and economic PV module, Battery Bank including Charge Control and Converter/bidirectional.

c) Load components consist of daily, monthly and yearly loads.

When performing a simulation, HOMER determines all system configurations from the input model data, then displayed the results of the sequential optimization according to the Net Present Cost (NPC) is also called Life Cycle Of Costs (LCOC). NPC is the current total value including the initial cost of all system components, the cost of component replacement during life time and maintenance costs. If a constrain analysis is required, HOMER will repeat the simulation process for each defined sensitivity variable. The relative annual error is about $3 \%$ and the error relative monthly is about 10\%. Figure 4 shows HOMER's architecture with a slight simplification and modification [9].

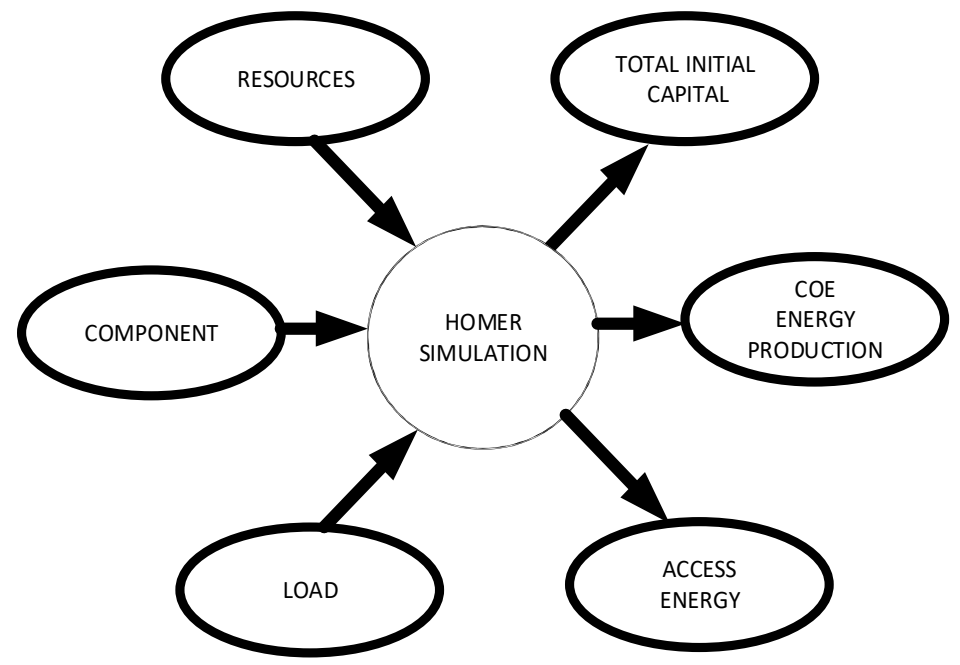

Fig. 4. Architecture of HRES.

The Output part needed in this research consists of:

a) Energy Production, is the energy generated by HRES

b) $\mathrm{COE}$, is the cost incurred by the production of energy

c) Excess Energy, is the excess energy between energy that can be Generated with the energy used

d) Total Initial Capital, is the Total initial capital prepared for the development of Micro-hydro to HRES. 


\section{Data Collection}

The data needed and processed in this research are:

a) The river water discharge data were collected from the preparation of planning studies of renewable energy infrastructure in East Kolaka Regency [10]. The monthly average discharge display of the Ambapa River on Figure 5.

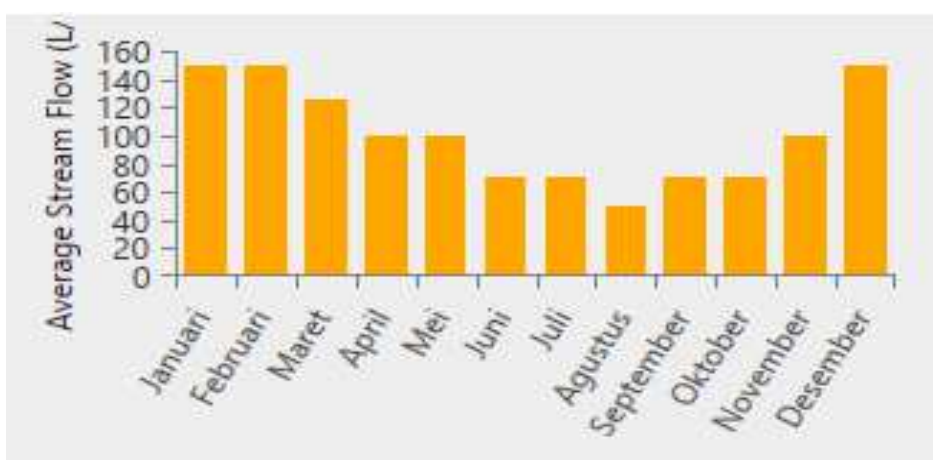

Fig. 5. Water Discharge Average Monthly Ambapa River

From Figure 5 obtained the average power of the Micro-hydro Systems:

- Power during the dry season (month 10-5) $=8.01 \mathrm{~kW}$

- Power during rainy season (month 11-4) $=14.46 \mathrm{Kw}$

b) Sunlight radiation data were obtained from the body of Meteorology, climatology and Geophysical district. Kolaka [11], with coordinates $3.13^{\circ}$ and $4.35^{\circ} \mathrm{LS}-121.05^{\circ}$ and $121.99^{\circ} \mathrm{BT}$. Display of average sunlight radiation (Figure 6).

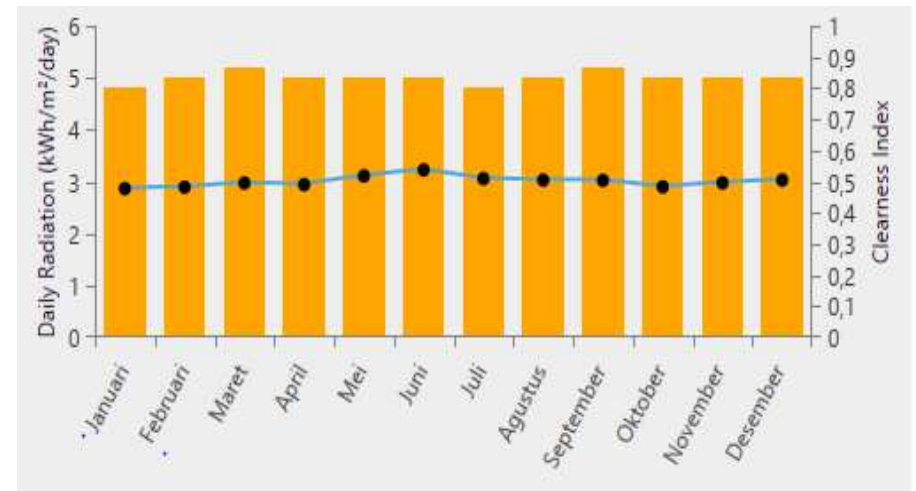

Fig. 6. Solar Radiation average on Ambapa Village.

c) Daily expenses

The survey results obtained daily load Data with installed power of each household is 900 Watt and 2 Ampere. The electricity average daily as shown in Figure 7. 


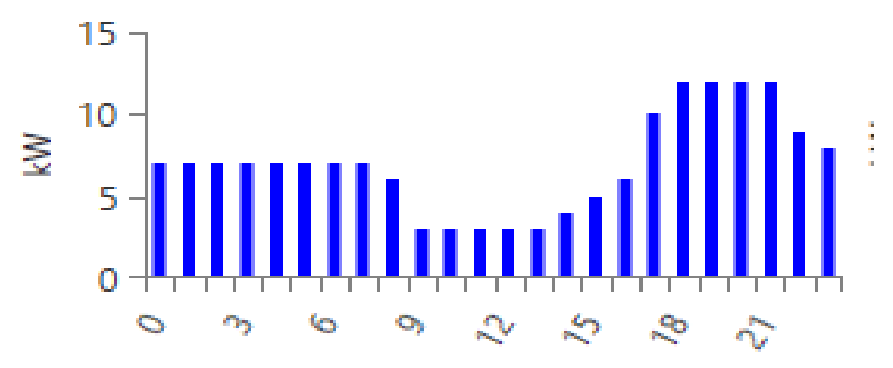

Fig. 7. The electricity daily expenses of Ambapa village.

From Figure 7 will be obtained energy and load as follows:

Average daily energy 24 hours $\quad=122.59 \mathrm{kWh} /$ year

Peak load Day (18.00-22.00) $\quad=11.6 \mathrm{~kW}$

Average load 24 hours $\quad=6.89 \mathrm{~kW}$

d) Technical specifications of HRES

Main components technical specifications of the main components of HRES are displayed on table 1 and table 2 .

Table 1. Micro-hydro and PV component specifications

\begin{tabular}{|c|l|l|}
\hline \multirow{2}{*}{ N0. } & \multicolumn{2}{|c|}{ Component Specifications } \\
\cline { 2 - 3 } & \multicolumn{1}{|c|}{ Micro-hydro (Survey) } & \multicolumn{1}{c|}{ PV Module* } \\
\hline 1. & Nominal Power 100 KW & Power of module 100 Wp \\
\hline 2. & Life time 25 years & Life time 25 years \\
\hline 3. & Head 23 meters & Derating Factor 90\% \\
\hline 4. & Flow Design 150 liters/s & No Tracking System \\
\hline 5. & Minimum Flow Ratio 25\% & Slope Degree 5.2 \\
\hline 6. & Maximum Flow Ratio 100\% & Efficiency 18.69\% \\
\hline 7. & Efficiency Turbine-gen 56\% & Dimension 1.580x808x35 mm \\
\hline \multicolumn{2}{|c|}{$*$ APAMSI [12]. } \\
\hline
\end{tabular}

Table 2. Converter and Battery Component specification

\begin{tabular}{|c|l|l|}
\hline \multirow{2}{*}{ N0. } & \multicolumn{2}{|c|}{ Component Specification } \\
\cline { 2 - 3 } & \multicolumn{1}{|c|}{ Converter** } & \multicolumn{1}{c|}{ Battery** } \\
\hline 1. & Power Rating 6 Kw & Capacity $83.4 \mathrm{Ah}$ \\
\hline 2. & Efficiency $95 \%$ & Voltage 12 Volt \\
\hline 3. & Life time 10 years & Efficiency $80 \%$ \\
\hline 4. & Voltage 12 Volt & Min State of Charge 40\% \\
\hline 5. & Relative Capacity 100\% & Life time 10 years \\
\hline \multicolumn{2}{|c|}{$* *$}
\end{tabular}
** APAMSI [12].

e) The cost of the main components of HRES

Capital cost, replacement, operational and Maintenance (O \& M). Each of the main components as shown in table 3. 
Table 3. Main Component Cost of HRES

\begin{tabular}{|c|l|r|r|r|}
\hline No. & \multicolumn{1}{|c|}{ Component } & \multicolumn{1}{c|}{$\begin{array}{c}\text { Capital } \\
(\mathrm{Rp})\end{array}$} & $\begin{array}{c}\text { Replacement } \\
(\mathrm{Rp})\end{array}$ & $\begin{array}{c}\text { O \& M Cost } \\
(\mathrm{Rp} / \text { years })\end{array}$ \\
\hline 1. & Photovoltaic** & $4,000,000$ & 0 & 0 \\
\hline 2. & Micro-hydro* & $250,000,000$ & 0 & $24,000,000$ \\
\hline 3. & Converter** & $26,000,000$ & $52,000,000$ & 0 \\
\hline 4. & Battery** & $4,000,000$ & $8,000,000$ & 0 \\
\hline \multicolumn{5}{|c}{ *ESDM,2014 [3]. } \\
** APAMSI [12].
\end{tabular}

Furthermore, conducted a simulation to get an optimization model of HRES Ambapa village by using the HOMER Pro 3.10.3.

\section{Result and Discussion}

\subsection{Result}

Optimization generates several options combination optimization results from schematic PV components, Battery, Micro-hydro and Converter featuring each NPC, COE, Initial Capital and Operating Cost from HRES as in Figure 8. Selection of the lowest NPC based

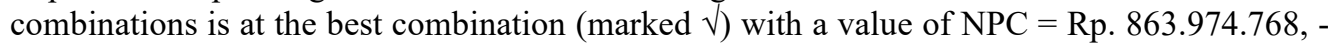
and a photovoltaic power contribution of $11.5 \mathrm{~kW}, 48$ battery amount, Power contribution of Micro-hydro $=19 \mathrm{~kW}$, Power of Converter $=6 \mathrm{~kW}$ and $\mathrm{COE}$ value $=$ Rp. 1,107. -

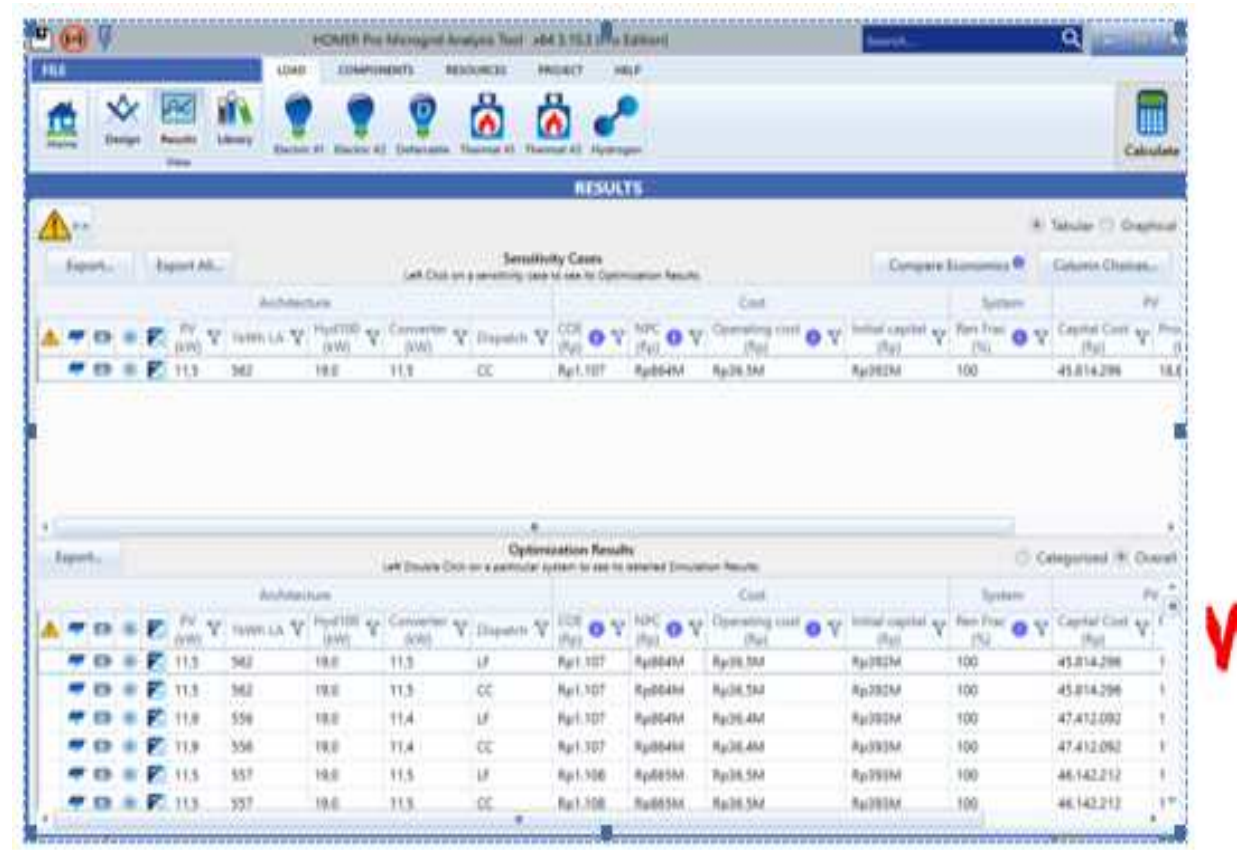

Fig. 8. Optimization Results of HRES. 
Similarly, the figure 9 displays the cost of Initial Capital, Replacement, O\&M Cost of each component HRES with the cost of PV = Rp. 45,815,294, Micro-hydro = Rp. 560,260,397. Converter Rp. 125,919,441 and Battery = Rp. 131,980,636. The value of Micro-hydro component in 2019 (already in the year 2014) with the remaining life time 25 years is Rp. $250,000,000$, So the total value of Initial investment of Rp. 392,470,986 - Rp. 250,000,000 = Rp. 142,470,986 and the total investment value of HRES Rp. 863,974,768.

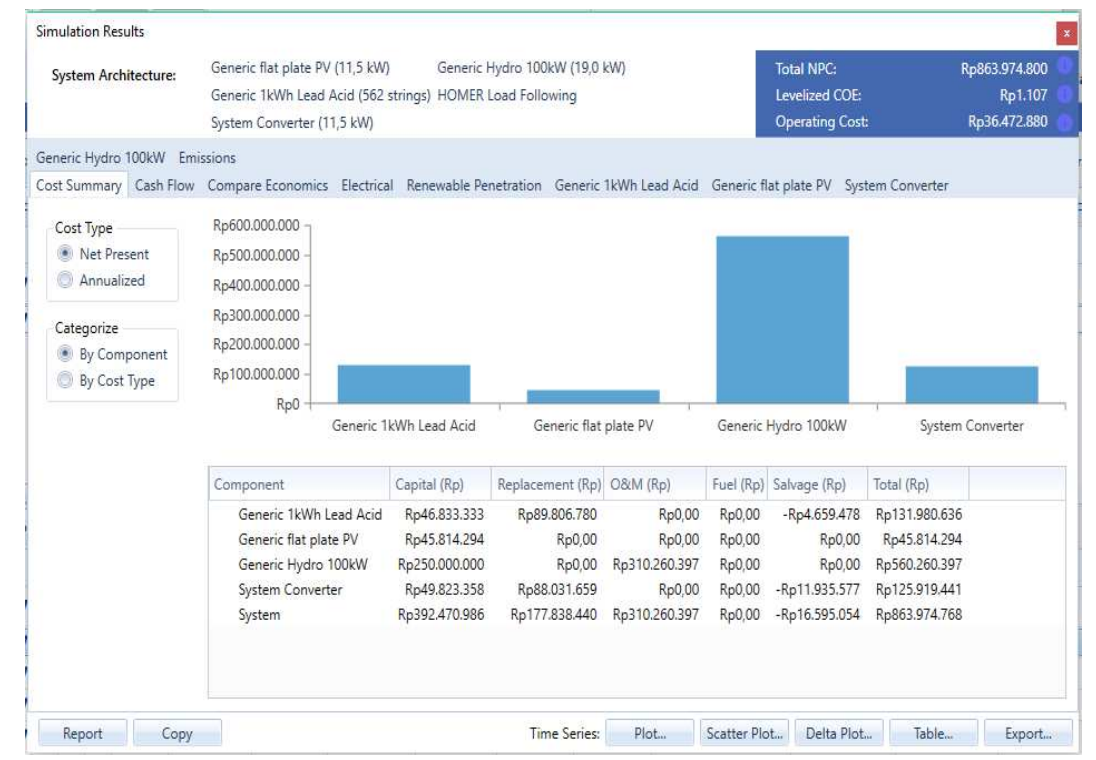

Fig. 9. Main Component Cost of HRES.

Table 4 displayed each energy source supplying energy to meet the needs of electrical energy simultaneously and continuously.

The optimal distribution of energy supply is calculated based on the lowest total NPC. The production of Micro-hydro energy source amounted to 103,780 kWh/year $(84.20 \%)$ and Photovoltaic amounting to $18,810 \mathrm{kWh} /$ year $(15.80 \%)$. Total energy contributions from $122,590 \mathrm{kWh} /$ year $(100 \%)$.

Table 4. Contribution of Micro-hydro and PV Power

\begin{tabular}{|c|c|c|}
\hline \multirow{2}{*}{ Production } & kWh/year & $\%$ \\
\hline PV & 18,810 & 15.80 \\
\hline Micro-hydro & 103,780 & 84.20 \\
\hline Total & 122,590 & 100.00 \\
\hline
\end{tabular}

Figure 10 shows the average contribution of Micro-hydro and PV production. The average contribution of Micro-hydro power production adjusts the change of the monthly water discharge and the average production contribution of PV power is fixed each month based on HOMER's optimization. 


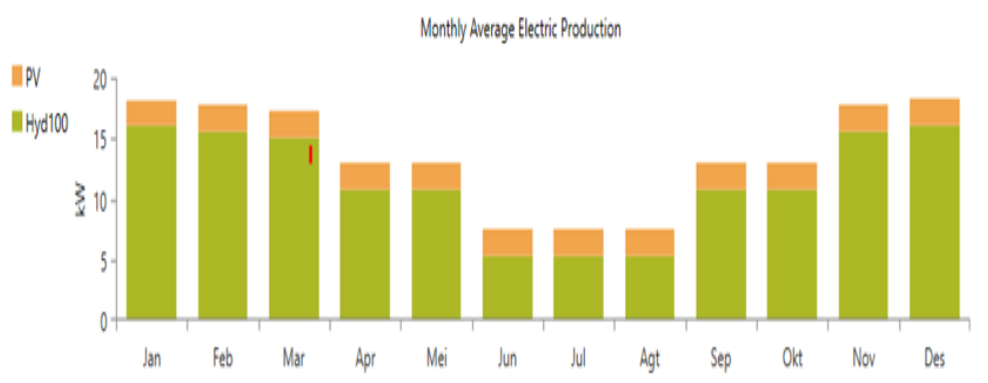

Fig. 10. Chart of Micro-hydro and PV contribution.

From June to August, the total contribution of MPHES amounted to $6.96 \mathrm{~kW}$ and a peak load of $11.6 \mathrm{~kW}$, so there will be blackout at night for 3 consecutive months. Therefore, the efforts of energy restriction of every household of $6.96 \mathrm{~kW} / 115$ houses $\mathrm{x} 24$ hours $=1,450 \mathrm{Wh}$ per day, provided that each household pay a monthly electricity fee of $=1,450 \mathrm{Wh} /$ day $\mathrm{x} 30$ days $x$ Rp. 1.107/KW = Rp. 48.238 and HRES is feasible and enforceable in Ambapa village without any power outage due to lack of water discharge. Acquired electrical fee (Rp. $1,107 / \mathrm{kWh}$ ) which is still cheaper than the price of PLN electricity tariff of Rp. $1,352 / \mathrm{kWh}$, although monthly electricity dues every household increased by $60 \%$ from Rp. 30,000 per month to Rp. 48,238 per month. Total excess energy due to the optimization of HRES and the energy restriction of each household (Rp. 1,737 kWh/year) can be an energy reserve of HRES.

\subsection{Discussion}

The results of the analysis using the Hybrid Optimization Model of Energy Renewable show that the hybrid resource between Micro-hydro and Photovoltaic will be able to overcome Micro-hydro's unsustainability caused by reduced river water discharge in the long dry season [13]. Solar radiation during the day will be converted into electrical energy through photovoltaic modules and the energy produced will be stored in a battery which will then together with micro-hydro power supply electricity to the user community at night, especially in the dry season. Of course, efforts to mix the resources caused additional energy costs charged by the community because of the addition of components and operating costs maintenance of Photovoltaic resource [2]. However, this research shows that increasing the total cost of the benefits received by the user community with a useful life of 25 years caused an increase in costs charged by the user community that will not exceed the PLN electricity tariff [14]. Nevertheless, the optimization process is done by choosing the lowest cost alternative of Rp. 1,070/kWh, so that people can enjoy sustainable electricity at a low cost. In addition, efforts are also made to ensure that the cost per $\mathrm{kWh}$ does not exceed the predetermined tariff, so there is also an energy restriction in each house of $1,450 \mathrm{kWh} /$ day. If there is an energy usage that exceeds the energy limit, then automatically the energy supply to the house concerned is cut off. The electricity supply will automatically recover again the next day.

The results of the analysis of the resources hybrid using the Hybrid Optimization Model of Energy Renewable also show that Micro-hydro and Photovoltaic resources jointly supply electrical energy to the user community with a photovoltaic supply of $15.8 \%$ and additional energy costs from Rp. 30,000 to Rp. 48,238 per month. Even though energy costs have 
increased, electricity in the village of Ambapa will always be available at any time. So, Hybrid of Micro-hydro Solar Photovoltaic (PV) energy sources and limiting the energy use of each household carried out simultaneously in both the rainy and dry seasons are the solutions so that not only electricity supply can be sustainable [15] but also low cost.

\section{Conclusion}

Based on the analysis of the development results Micro-hydro become HRES in Ambapa village, then it can be concluded that Micro-hydro development to HRES is worth applying in Ambapa village because HRES can provide energy sustainably and Electricity fee (Rp. $1,107 / \mathrm{kWh}$ ) is smaller than PLN electricity fee, Adding PV component with the contribution of energy supply as much as $18,810 \mathrm{~kW} /$ years $(15.80 \%)$ will result in adding dues per month households to Rp. 48,238 and energy supplies are available at all times and the effort to restrict the energy consumption of each household maximum $1,450 \mathrm{Wh} /$ day will reduce peak load to $6.96 \mathrm{~kW}$ and increase the electricity excess up to Rp. 1,737 kWh/year.

\section{References}

[1] BPS Kolaka Timur, Kolaka Timur dalam Angka 2014. BPS Kolaka Timur, 2014.

[2] B. Kahar and R. Hantoro, "A Review of Solar-Powered Boat Development," IPTEK, vol. 27, no. 1, p. 9, 2016.

[3] C. D. Dumitru and D. Adrian-Vasile, "Analysis of A Hybrid Renewable Energy System on the Mures Valley Using HOMER," in The International Conference Interdisciplinarity in Engineering INTER-ENG, 2011, p. 112.

[4] L. E. Teixeira, J. Caux, A. Beluco, I. Bertoldo, J. A. S. Louzada, and R. C. Eifler, "Feasibility study of a hydro PV hybrid system operating at a dam for water supply in southern Brazil," $J$. Power Energy Eng., vol. 3, no. 09, p. 70, 2015.

[5] S. Kanata, "Kajian ekonomis pembangkit hybrid renewable energi menuju desa mandiri energi di Kabupaten Bone-Bolango,” J. Rekayasa Elektr., vol. 11, no. 3, pp. 114-122, 2015.

[6] D. K. Lal, B. B. Dash, and A. K. Akella, "Optimization of PV/wind/micro-hydro/diesel hybrid power system in HOMER for the study area," Int. J. Electr. Eng. Informatics, vol. 3, no. 3, p. 307, 2011.

[7] J. B. Fulzele and S. Dutt, "Optimium planning of hybrid renewable energy system using HOMER,” Int. J. Electr. Comput. Eng., vol. 2, no. 1, p. 68, 2012.

[8] M. A. M. Bhuiyan, A. Deb, and A. Nasir, "Optimum planning of hybrid energy system using HOMER for rural electrification,” Int. J. Comput. Appl., vol. 66, no. 13, 2013.

[9] S. Nafis, M. Aman, and A. Hadiyono, "Analisis Keekonomian Penerapan Pembangkit Listrik Tenaga Surya pada Sistem Ketenagalistrikan Nias," Ketenagalistrikan dan Energi Terbarukan, vol. 14, no. 2, pp. 83-94, 2016.

[10] ESDM Prov. Sultra, Penyusunan Studi Perencanaan Infrastruktur Energi Terbarukan (FS dan DED) Micro-hydro di Kabupaten Kolaka Timur. Dinas Energi Sumber Daya dan Mineral, 2014.

[11] Badan Meteorologi Klimatologi dan Geofisika, Radiasi Sinar Matahari Desa Ambapa, KecamatanTinondo Kab. Kolaka. Badan Meteorologi Klimatologi dan Geofisika, 2014.

[12] APAMSI, Buku Panduan Pengoperasian dan Perawatan Pembangkit Listrik Tenaga Surya. Jakarta: Asosisasi Pabrikan Modul Surya Indonesia, 2014.

[13] M. Rezky, S. Wahri, and G. F. Rika, "Desain Sistem Pembangkit Listrik Hybrid Micrhydro-PV Array," J. Arus Elektro Indones., 2016.

[14] Peraturan Menteri Energi dan Sumber Daya Mineral Republik Indonesia, Permen No. 28 Tahun 2016 Tentang Tarif Tenaga Listrik yang Disediakan Oleh PT. Perusahaan Listrik Negara 
(PLN). 2016.

[15] M. S. Thakur, B. Gupta, V. Kumar, and M. Pandey, "Design and optimization of hybrid renewable energy system $(2 \mathrm{MWH} / \mathrm{D})$ for sustainable and economical power supply at JEC Jabalpur," Int. J. Curr. Res. Rev., vol. 4, no. 20, p. 188, 2012. 